\title{
Amaranth Grain and Greens for Health Benefits
}

\author{
Kaufui V Wong* \\ Department of Mechanical and Aerospace Engineering, University of Miami USA
}

Submission: December 12, 2016; Published: January 31, 2017

*Corresponding author: Kaufui V Wong, Department of Mechanical and Aerospace Engineering, University of Miami, USA, Email: kwong@miami.edu

\begin{abstract}
With regards amaranth greens and its healthful benefits including prevention against cardiovascular disease and hypertension, there is evidence in the literature about these benefits. One objective of the current work is to suggest the amaranth green as a suitable home garden vegetable for peoples worldwide to encourage more consumption of vegetables. That it is a practice in many parts of Asia and Oceania, should be an encouragement for the peoples in the Americas and Europe. It tastes like spinach, but with a stronger flavor. The many health benefits of the amaranth grain, greens and oil are briefly outlined. Owing to its resilience under many climatic conditions, the amaranth green should be grown in households worldwide as a vegetable. Amaranth grain agriculture may be expanded worldwide since the gluten problem (from wheat, rye and barley) has become better known.
\end{abstract}

Keywords: Vegetable; Phyto nutrients; Cardiovascular disease; Hypertension

\section{Background}

The Amaranth is an ancient plant, which has been estimated to be eaten by humans for about eight thousand years. Indeed, the ancient Greeks used the Amaranth. Amaranthus, together known as amaranth, is a diverse genus of short-term perennial plants [1]. A number of amaranth species are grown as leaf vegetables, as a cereal or cereal substitute, and garden plants for landscaping purposes. Literature survey performed about this topic revealed a list of health benefits resulting from eating amaranth greens, amaranth seeds and food products made from amaranth flour, as well as consuming amaranth oil.

\section{Health Benefits of Amaranth}

There is a recipe for preserved duck eggs (Chinese 'hundred year old eggs') stir-fried with pink amaranth leaves. This practice must have been derived from using the beneficial phytonutrients of the amaranth to counteract whatever that is not as healthy (free radicals) from the putrefied proteins in the preserved duck eggs. It is an acquired taste, but preserved eggs do have a following among the Chinese population. It is speculated that the amaranth made up to eighty percent of the Aztec's diet [2]. It was certainly a healthy diet, because of the absence of gluten and refined sugar [3-5]. That their diet was low in animal fats was probably also a contributory factor to the health of the Aztecs.

In [6], it was concluded that a threatened Amaranthus grain species may have benefits if used to interbreed with more commonly cultivated species types in agriculture. Reference [7] from 1992 was a state of the art review about the published literature on grain amaranth agriculture and production, which was very active in the 1980's. In 1989, Mallory studied agronomy and production from 1919 to 1988 [8]. He had a bibliography of 192 citations with abstracts, with many on the cultivated varieties of amaranth. Reference [9] is a more recent article on the amaranth grain; their findings were that the nutrients from the amaranth grain benefited the health of young normal mice, or at least normal with respect to the fat content in their blood samples. In a book [10], the researchers included amaranth as a beneficial crop grown and indigenous to Latin America. In [11], there is a listing of fourteen reasons to eat amaranth grain. Below, written with references, are a selected number (nine) of explanations.

A. Similar to quinoa, amaranth is not a true grain but the seed of the amaranth plant. It is very productive as the plant is capable of yielding sixty thousand seeds $[11,12]$. At six generations per year in suitable climate [12], the amaranth is really productive. In addition, it does not contain gluten, which has been found to have a general negative role in the human body [3,4].

B. Most grains like barley are short on lysine, an amino acid. The amaranth grain contains lysine [13]. Hence; amaranth grain contains a complete protein as all the essential amino acids are present. 
C. Amaranth's protein content is about thirteen percent $[13,14]$, or more than most other grains. In contrast, a cup of long-grain white rice has 13 grams of protein, which is half the amount found in amaranth.

D. Amaranth can thrive at nearly any altitude in tropical and temperate climates if it has moist, loose soil with decent drainage. It can even live in water-shortage settings if the plants are mature $[12,13]$. Amaranth is grown worldwide in countries like China, Russia, Thailand, Malaysia, Nigeria, and Mexico. Various preparations of amaranth are considered traditional foods in parts of India, Nepal, and the African continent. There are limited number of farmers cultivating amaranth in parts of the United States of America (USA), comprising Florida, North Dakota and Nebraska. Although in many other parts of the USA, amaranth is so invasive that many Americans view them as a wild weed that impedes the growth of other less aggressive plants [15].

E. Amaranth seeds or grain may be consumed, and so can the leaves and flowers. The genus Amaranthus has more than 60 different species [1]. They are commonly used in Asian and Caribbean fares. The popular Chinese version of amaranth greens dish consists of a low-temperature light stir-fry or saute of the greens in oil, garlic, salt and spices to taste. The Caribbean callaloo dish which requires a green has African roots [16]. The green most frequently used in callaloo is amaranth green, but the taro root green is popular in Trinidad [16]. The African Americans have made a similar vegetable stew dish with collard greens [16]. In the use of taro leaves, the people of Trinidad are similar to those in Fiji, where the taro leaf green is the most important vegetable cash crop for the people of Fiji [17]. The amaranth greens are also cultivated and eaten by the other peoples of Oceania [17].

F. Amaranth contains a wealth of minerals [15]. It offers calcium, magnesium, potassium, phosphorus, and iron. One cup of uncooked amaranth has thirty-one percent of the recommended daily allowance (RDA) for calcium, fourteen percent for vitamin $\mathrm{C}$, and eighty-two percent for iron [11]. On the other hand, one cup of cooked amaranth has forty-percent of the RDA for magnesium, thirty-six percent for phosphorus and over a hundred and five percent for manganese.

G. Amaranth oil is therapeutic for cardiovascular disease (CVD) and hypertension [18]. Reference [18] is a 2007 publication, the researchers being mostly Russian. There was a 1996 American study which discovered that amaranth oil could reduce low-density lipoprotein (LDL) and total cholesterol in female chickens [19]. A2003 publication demonstrated that amaranth has phytosterols [20] with its cholesterol-diminishing characteristics.
H. Amaranth grain provides another breakfast choice that does not have to include added refine sugar. Amaranth's tiny grains take on porridge-like texture when cooked, making it a reasonable choice for breakfast. In actuality, amaranth porridge is an old-style breakfast in India, Mexico, Peru and Nepal. The minor aim of the current work is to caution against the addition of refined sugar to any recipes involving amaranth grain or greens [5].

I. Amaranth grain is a good candidate for a dietary fiber food. It provides 13 grams of fiber per uncooked cup contrasted to 2 grams of a similar quantity of long-grain white rice $[11,15]$. One's body is kept regular with the help of dietary fiber.

\section{Ancient Grain that does not contain Gluten}

As a seed that does not contain gluten, or a similar protein zein (such as in corn), amaranth grain seems like a seed 'grain' that is set to take off in popularity. It is easy to cook like rice and oats. Unlike rice, it does not have arsenic taken up naturally from the environment [21]. In the standard American diet (SAD), the breakfast meal normally consists of some kind of cereal, dairy product and refined added sugar. The cereal would likely contain some kind of product obtained from wheat, rye and barley, with the gluten protein present. To have a healthier replacement, oats, rice and amaranth grain are offered as alternatives. Rice porridge has been consumed in China and in Chinese communities outside of China for a while. Similarly, amaranth porridge has been consumed in India, Mexico, Peru and Nepal. The caution here is that no refined sugar should be added to the porridge, and savory recipes of the porridge may be propagated for popularity and health.

The after-meal dessert is also a meal-end-dish in the standard American diet that would be hard to let go for many. This one is open to any kind of novel recipes and ideas. Amaranth flour is available, and fruits (fresh, dried and frozen) are available as ingredients. This holds true for oats too. Whole fruits may be used as fine desserts by themselves. To cut down the amount of glucose and fructose consumed per unit weight of food, and to raise the relative amount of fiber per unit weight of food, amaranth grain or oats could be use in addition (subtracting some of the fruit). The nutrient/calories or N/C formula to evaluate a food item would be raised in the dessert, and hence be more healthful. Care should be taken that if any heat is involved in cooking or baking, it does not go above $25^{\circ} \mathrm{F}[22,23]$; otherwise, noxious food products would be formed. This general fact is applicable to the preparation of regular main dishes also.

\section{Discussion and Conclusion}

Amaranth grain and greens give significant health benefits. In particular, the consumption of amaranth for CVD and hypertension has been proven. If cultivated in one's own garden, this traditional vegetable can be minimal in cost and 
effort, making it a smart recommendation. Amaranth seeds are used as cereals or as a cereal component. Amaranth oil has been shown to be beneficial for health. Amaranth flour is used in many food products. Since it does not contain gluten, its availability is a good replacement for wheat (rye, barley which also has gluten) and wheat products, as well as for the derived flour. It is suggested that amaranth greens be cultivated in one's garden, wherever possible.

\section{Acknowledgment}

This paper is dedicated to all my social media friends who have encouraged me with my work in nutrition and health, with a focus on phytonutrients.

\section{References}

1. Wikipedia "Amaranth".

2. Coe SD (1994) Americass First Cuisines. University of Texas Press. ISBN 9780292711594.

3. Wong KV (2015) "Stresses caused by Too Much Wheat and Sugar." Accepted 2/28/15. Global Journal of Immunology and Allergic Diseases, pharmapublisher.com 3(1).

4. Wong KV (2015) “A Perspective of One Important Risk Factor of Type 2 Diabetes in Hispanic and Asian Minorities." 3(1).

5. Wong KV (2016) "Strategies to Strike out Sugar" J of Epidemiology and Public Health Reviews, Sciforschen publishers 1:3.

6. Marcone MF (2001) "Starch properties of Amaranthuspumilus (seabeach amaranth): a threatened plant species with potential benefits for the breeding/amelioration of present Amaranthus cultivars." Food chemistry 73(1): 61-66.

7. Kauffman CS (1992) "The status of grain amaranth for the 1990s." Food Reviews International 8(1): 165-185.

8. Mallory E (1989) Agronomic studies and production practices, 1919 to 1988: 192 citations with abstracts. Bibliography of cultivated amaranths (USA).

9. Cazarin CB, Chang YK, Depieri M, Carneiro EM, de Souza AS, et al. (2012) "Amaranth Grain Brings Health Benefits to Young Normolipidemic Rats." Food and Public Health 2(5): 178-183.

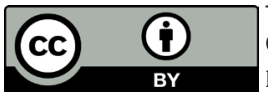

This work is licensed under Creative Commons Attribution 4.0 License DOI: 10.19080/NFSIJ.2017.02.555584
10. Guzmán Maldonado SH, Paredes Lopez 0 (1998) "Functional products of plants indigenous to Latin America: amaranth, quinoa, common beans, and botanicals."Functional foods. Biochemical and processing aspects 19: 293-328.

11. Coles T "Benefits of Amaranth: 14 Reasons to get into this grain." Huntington Post, USA.

12. Délano-Frier JP, Martínez-Gallardo NA, Martínez-de La Vega O, SalasAraiza MD, Barbosa-Jaramillo ER, et al. (2004) "The effect of exogenous jasmonic acid on induced resistance and productivity in amaranth (Amaranthushypochondriacus) is influenced by environmental conditions." J Chem Ecol 30(5): 1001-1034.

13. Becker R, Wheeler EL, Lorenz K, Stafford AE, Grosjean OK, et al. (1981) "A compositional study of amaranth grain." Journal of Food Science 46(4):1175-80.

14. McMasters MM, Baird PD, Hazapfel MM, Rist EC (1955) “Preparation of starch from Amaranthuscruentus seed." Econ Bot 9(3): 300-302.

15. Ravensthorpe M "Amaranth: a gluten-free grain rich in protein and minerals." 10/14/2014.

16. Wikipedia "Callaloo".

17. Wikipedia "Fijian Food".

18. Martirosyan DM, Miroshnichenko LA, Kulakova SN, Pogojeva AV Zoloedov VI (2007) "Amaranth oil application for coronary heart disease and hypertension." Lipids Health Dis 6:1.

19. Qureshi AA, Lehmann JW, Peterson DM (1996) "Amaranth and its oil inhibit cholesterol biosynthesis in 6-week-old female chickens." J Nutr 126(8):1972-1978.

20. Marcone MF, Kakuda Y, Yada RY (2003) "Amaranth as a rich dietary source of $\beta$-sitosterol and other phytosterols." Plant Foods Hum Nutr 58(3): 207-211.

21.Wong KV (2016) "Rice Consumption and Hypertension" J of Epidemiology and Public Health Reviews, Sciforschen publishers 1(1).

22. Andrews R, "All about Cooking and Carcinogens." Precisionnutrition. com.

23. JägerstadM, SkogK (2005) "Genotoxicityofheat-processedfoods." Mutat Res 574(1-2): 156-172.

\section{Your next submission with Juniper Publishers will reach you the below assets}

- Quality Editorial service

- Swift Peer Review

- Reprints availability

- E-prints Service

- Manuscript Podcast for convenient understanding

- Global attainment for your research

- Manuscript accessibility in different formats

( Pdf, E-pub, Full Text, Audio)

- Unceasing customer service

Track the below URL for one-step submission

https://juniperpublishers.com/online-submission.php 